\title{
INJURED AND SUFFERING BODIES: THE TRAFFICKING AND FEMICIDE OF DOMINICAN IMMIGRANT WOMEN IN PUERTO RICO
}

\author{
OSVALDO Di PAOLO HARRISON*
}

Austin Peay State University in Clarksville, Tennessee, United States of America

\begin{abstract}
After drug and weapon trafficking, trafficking of women is one of the most lucrative businesses in the world. According to sociologists César Rey Hernández and Luisa Hernández Angueira in People Trafficking in Puerto Rico: The Challenge of Invisibility (2010), fifty percent of the victims are women and minors. This translates to 2.7 million women and girls that are enslaved in this inhuman business. Puerto Rico is no exception. One of its main problems is the slavery of Dominican women who, in search of a better life in Puerto Rico, are lured to illegally migrate to the island for better opportunities. However, once in the new territory, they are imprisoned and forced to become prostitutes. In addition, femicide is another world-wide pressing issue. The World Health Organization (WHO) affirms that violence against women, between fifteen and forty-four years of age, is the leading cause of death, more than cancer, malaria, car accidents and war combined, and the report 'A Gendered Analysis of Violent Death', compiled by Small Arms Survey Center, fourteen out of twenty-five countries with the highest rates of femicide in the world are in Latin America and the Caribbean. This essay focuses on Life is a Sexually Transmittable Disease (2014) by Wilfredo Mattos Cintron. In this novel, the enslaved-immigrant girls and women constitute an injured body', a body that is merely diminished. The third-world prostitute's body is the material side of male-controlled dominance, subjugation and violence. Mattos Cintron's text denounces the 'suffering body of women'-rape, kidnapping, beating, femicide, their exclusion from human rights and sexual relegation. Moreover, along with patriarchy's power and the socioeconomic variables as responsible agents of creating the injured body, globalization and capitalism objectify and make women's bodies currency of the system.
\end{abstract}

KEYWORDS: femicide, sex trafficking, injured bodies, illegal immigration, Dominican, Puerto Rico

\section{Introduction}

By definition of the United Nations Declaration of the Elimination of Violence Against Women, violence against women consists of 'any act of gender-based violence that results in, or is likely to result in physical,

* OSVALDO DI PAOLO HARRISON (PhD 2010, University of Kentucky) is Professor of Latin American Literary and Cultural Studies at Austin Peay State University in Clarksville, Tennessee. E-mail: dipaoloo@apsu.edu. 
sexual, or psychological harm suffering to women.' The statement adds that it includes 'threats of such acts, coercion, or arbitrary deprivations of such liberty, whether occurring in public or private life' (Ritchers 1994: 2). On a large scale, the Theory of Violence comprises 'threats, intimidation, verbal abuse, coercion, and harassment as well as murder, sexual assault, rape and battering' (Parrot and Cummings 2006: 10). In addition, the United Nations Special Rapporteur for the Commission on Human Rights on Violence against Women: Its Causes and Consequences points out that women can be vulnerable in the family setting, in the community and by means of the state (Coormaraswamy 1994: 5). When it comes to violence in the community, Coormaraswamy gives the following examples: rape, sexual assault, commercialized violence (trafficking of women), sexual exploitation, sexual slavery and abuse of female migrant workers.

Trafficking of women, after drug and weapon trafficking, is one of the most lucrative business in the world (Hernández and Angueira 2010: 1). Since many legislators are still debating the meaning of sex trafficking, this essay will use the definition of the 2000 United Nations Trafficking Protocol:

The recruitment, transportation, transfer, harboring or receipt of persons by means of threat or use of force or other forms of coercion, of abduction, of fraud, of deception, of the abuse of power, or of a position of vulnerability or of the giving or receiving of payments or benefits to achieve the consent of a person having control over another person, for the purpose of exploitation. Exploitation shall include, at a minimum, the exploitation of prostitution of other or other forms of sexual exploitation, forced labor services, slavery or practices similar to slavery, servitude or the removal of organs (Siddharth 2010: $5)$.

According to sociologists César Rey Hernández and Luisa Hernández Angueira in People Trafficking in Puerto Rico: The Challenge of Invisibility (2010), fifty percent of the victims are women and minors. This translates to 2.7 million women and girls that are enslaved in this inhumane business (page 1) and the report Estimating Human Trafficking into the United States: Development of a Methodology, for the U.S. Department of Justice, states that around 17.500 women are trafficked into the United States (Clawson 2006: 4). Puerto Rico is no exception. One of island's pressing problems is the slavery of Dominican women who, in search of a better life, are lured to illegally migrate to the island for better opportunities. However, once in the new territory, they are imprisoned and forced to become prostitutes.

In addition, femicide is another world-wide pressing issue. This essay takes the definition of The United Nations Declaration on the Elimination of Violence against Women: 'any act of gender-based violence that results 
in, or is likely to result in, physical, sexual or psychological harm or suffering to women, including threats of such acts, coercion or arbitrary deprivation of liberty, whether occurring in public or in private life' (cited in Da Lomba 2004: 73). As stated by Women in an Insecure World: Violence against Women: Facts, Figures and Analysis, violence against women, between fifteen and forty-four years of age, is the leading cause of death, more than cancer, malaria, car accidents and war combined (Vlachová and Biason 2005: 1), and the report 'A Gendered Analysis of Violent Death,' compiled by Small Arms Survey Center, asserts that fourteen out of twenty-five countries with the highest rates of femicide in the world are in Latin America and the Caribbean (2016: 1).

This essay focuses on Life is a Sexually Transmittable Disease (2014) by Wilfredo Mattos Cintrón. In this novel, the enslaved-immigrant girls and women constitute an 'injured body', a body that is merely diminished. The third-world prostitute's body is the material side of male-controlled dominance, subjugation and violence. Mattos Cintrón's text denounces the 'suffering body of women'-rape, kidnapping, beating, femicide-their exclusion from human rights and sexual relegation. Moreover, along with patriarchy's power and the socioeconomic variables as responsible agents of creating the injured body, globalization and capitalism objectify and make women's bodies currency of the system.

The plot of Life is a Sexually Transmittable Disease focuses on the disappearance of the Dominican Herminia Toral. Her cousins hire a private detective named Isabelo Andújar to find out what happened to her. Herminia had arrived in Puerto Rico from the Dominican Republic, crossing, illegally, the dangerous Mona Passage a year ago. Her parents received a letter from her that simply said, 'get me out of here' (Cintrón 2014). Following clues, Andújar gets involved with a trafficking cartel responsible for the femicide of Herminia Toral and witnesses the femicide of Liliana Vodocq-another victim. Successfully, the detective discovers how women are deceived, enslaved, forced to practice prostitution and murdered if they try to escape. However, the 'Master', the top man in charge of the trafficking, flees to Guatemala. Andújar regrets not being able to capture him because he is sure that the cartel will continue somewhere else.

This alarming and tangible problem that faces Puerto Rico contributes to create injured bodies of prostitution. According to Kathleen Barry, in The Prostitution of Sexuality: The Global Exploitation of Women, prostitution is the greatest manifestation of male control and 'the cornerstone of all sexual exploitation' (Barry 1995: 9) and it 'becomes the foundation of the identity of woman. Prostitution makes all women vulnerable, exposed to danger, open to attack' (Doezema 2001: 26). In addition, Barry states that she is 
'taking prostitution as the model, the most extreme and most crystallized form of all sexual exploitation. Sexual exploitation is a political condition, the foundation of women's subordination and the base from which discrimination against women is constructed and enacted' (1995: 11).

Consequently, Dominican women enslaved to become prostitutes in Puerto Rico are injured and wounded bodies. Their corporeal figures are constantly threatened and susceptible to be attacked. According to Barry, trafficking of women takes more precedence in 'backward' and 'traditional' social groups. In the study of Indian and Pakistani women by Barry, 'trafficking focuses particularly on indigenous and aboriginal women who are from remote tribal communities where traditional family and religious practices either devaluate girl children or reduce girls to sex service, which enables and encourages parents to sell their daughters' (1995: 17). In contrast to Barry's study, Gloria Feldt, president of Plan Parenthood, in the United States, 'we tend to see the issue of trafficking and forced prostitution through the lens of our affluent democratic societies. In many cultures, women and girls have no power and very limited rights so that their vulnerability to sex trafficking is high' (quoted in Soriano 2000: 3).

In the case of the novel under analysis, it is best to combine these statements mentioned above. Puerto Rico does not have aboriginal women, who are sold by families because of being considered inferior due to gender and social practices, but it has cases where adolescents and children were forced to prostitute themselves by their own family (Angueira and Hernández 2014: 11). This territory of the United States ranks second in regards to inequality in Latin America. High poverty and illegal immigration contribute to sexual submission and trafficking of bodies (2014: 3). Moreover, the levels of violence on the island are high and the murder rate is similar to countries like the Republic of Congo, Ethiopia and already outdid Tanzania for killing rates (2014: 3).

In Mattos Cintrón's novel, Herminia Toral is smuggled into the island with the help of Dominican Aparicio Malverde. While she thinks that she is immigrating to live a better life, as soon as she arrives in the island, she becomes the possession of the 'Master', the chief of the band. He trains women and girls to be enslaved in the prostitution business. Once they are psychologically and physically submitted, they are sold to Mr. Epitafio, the owner of a night-club to satisfy his clients. The enslavement of foreign injured bodies is an advantage to the exploiter because the wounded bodies do not have any social circle to ask for help. Note that Herminia manages to send a letter to the Dominican Republic to be rescued because she has no family on the island. In 'Strengthening Domestic Violence Theories', Michel Bograd explains that we coexist in a context erected by the intersection of power-race, social class, gender and sexual orientation-and mechanisms 
of oppression (prejudices, gender inequality, etc., see Bograd 2005). The vulnerable situation of Herminia and all of the women who suffer due to sexual enslavement is due to the intersection of these variables. Secondly, Herminia, as a woman, is in a more unfavorable position for the mere fact of being female. She is perceived as docile and fearful. Thirdly, Herminia is an immigrant and her social class on the island is that of the poor expatriate with no tangible resources (Di Paolo Harrison 2017: 35).

In 'Women Trafficking: Connections and Disconnections of Gender, Migration and Human Rights', Susana Chiarotti explains that body trafficking in Latin America exhibits the following:

[...] the classic trafficking of women: people deceived and forced by traffickers to work against their will and in enslaving conditions. The organized bands employ violent methods, achieving intimidation of victims, and the impunity of their crimes. In some cases, the complainants are murdered when the process is initiated, while others are localized and recruited once more (Chiarotti 2004: $53)$.

The manner in which the trafficking takes place in the novel of Mattos Cintrón coincides with Chiarotti's statement and with the previous research of the injured body, previously explained.

Both, Herminia and Liliana are deceived and lured to immigrate from the Dominican Republic. As Kara Siddharth states in Sex Trafficking: Inside the Business of Modern Slavery, 'deceit entails the false offer of a job, travel or other income generating opportunity for the purpose of acquiring a slave' (Siddharth 2010: 7), and when people are distressed because of having no work opportunities, they became easy prey. Liliana Vidocq, the enslaved prostitute, retells the story of how she crossed the border:

When we left the boat, a man was waiting for us. He was my countryman. He looked serious and friendly. Selected several women and some children, girls and boys, and locked us up in a van. It is necessary to avoid being seen by people, because they call the police and we will all go to jail, he would tell us. Even if I could have seen through the window, I would have not been able to say where we were. I do not know this country... They took us to a house in the countryside. At the beginning they separated us and they put us in dungeons (Cintrón 2014: 183).

Note that the deceiver is from the same country as the victims, a tactic employed to generate trust and ensure an easier enslavement. Also, one in three Dominicans live in poverty and women typically have no economic resources. In 2010, the employment rate of men was $61 \%$, while the rate of women was only $33 \%$ (2012: 1). These economic trials explain the reason why most Dominican women are subjected to deceit and slavery. It is 
desperation for survival that forces them to migrate to Puerto Rico and other parts of the United States. A report by the Migration Policy Institute (MPI) informs that more women than men leave the Dominican Republic. Between 1970 and 2012, 56\% of the immigrants were women (Chiamaka and Batalova 2014: 1).

Regarding the comment of the deceiver that they needed to hide quickly, on the one hand, it is in part to avoid seeing the existence of trafficking. On the other hand, Puerto Ricans have contempt towards Dominican immigrants on the island. This poses another threat for Liliana and Herminia, because people see them as inferior and they would likely not extend support towards them. Some of the frequent criticism that Dominican receive from Puerto Ricans are well summarized by anthropologist César Hernández:

To give for certain that all of them are niggers or illegal 'enyola'os'-as some schoolchildren call Dominican classmates; a disparage to those who are not black or have an inferior educational level; label them as usurpers of employment; blame them for drug issues; or obviate the contribution of those who inserted in the society decades ago, are these only a few of the most common modes of rejection that faces this immigrant population (Torres 2000: 5).

All of these issues contribute to the injured body. For example, when the prostitute Liliana Vidocq talks to the detective, who is investigating the disappearance of Herminia, she does not know how to begin her story. The narrator explains that the prostitute could barely talk because she 'had a ballast tongue due to the pain that nailed the roof of her mouth, and in her throat, the scream of the corpses that had to die in that threshold to avoid greater punishments to the body, swirled around her' (Cintrón 2014: 183). When she finally is able to manage her pain, Liliana tells the detective that when she was kidnapped 'three men arrived and abused her. I received many hits when I would resist at the beginning... After a while I gave in and I did everything they wanted' (Cintrón 2014: 184).

In Sex Trafficking: Inside the Business of Modern Slavery, Kara Siddharth enumerates the cruelties that the injured bodies have to withstand. She explains that 'the brutalities associated with sex slavery are perverse, violent, and utterly destructive. Whips, cigarette burns, broken bones, starvation-every slave has suffered these tortures, but sex slaves suffer each of these as well as innumerable counts of rape-ten, fifteen, twenty or more times per day' (2009: ix). In the novel, the 'Master', leader of the trafficking gang, affirms that when someone gets into this business, the job must be done without 'sentimentalism'. He even admits that every aspect of the business has to be done: 
With cold certainty that the results are the only criterion for success and for this reason, there cannot be hesitation. The merchandise has to be prepared for the consumer. That means that it has to be stripped of all resistance. Sculpting the human body and soul to leave them free of all the ties that they prevented from transparently offer themselves to the sexual appetite of others (Cintrón 2014: 109).

The psychological and physical torture allows powerful male abusers to appropriate and manipulate the identity of the victim, creating an injured corporality that is intrinsically related to the mind and the performativity of the oppressed woman. One of the reasons for the strong presence of the trafficking business and the need to create injured bodies is due to its profitability. In an interview, Jorge Zepeda Patterson, a Mexican writer and journalist explains that

this primitive tare that is sexual slavery, that one would place in the past, in reality it has prospered with globalization and it has increased. There is enormous profit in this business that one character, taken from a real testimony, says it: 'drug is a merchandise that is sold only once, while a woman's body can be sold every night' (Zepeda Patterson in Gaffoglio 2015: 2).

In the novel under study the 'Master' laments the loss of the lucrative bodies of Liliana and Herminia (Cintrón 2014: 198). In addition, he confesses that by means of globalization, that is to say computers and internet he could profit with pornographic films using children. He even says that the whole world could be his market and praises the 'wonders of modern technology' (Cintrón 2014: 200). The 'Master' is not exaggerating. His trafficking business is indeed very lucrative. The selling of trafficked sex slaves to bordellos yielded 1 billion dollars in 2007 (Siddharth 2010: 19). In the novel, the 'Master' breaks down these women to sell them to Don Epitafio, the owner of a bar and bordello where the slaves are forced to work in prostitution. Moreover, the industry of exploitation of trafficked sex slaves produced 51.3 billion in profits in 2007 (Siddharth 2010: 19).

This dark panorama of sex trafficking and the existence of injured bodies is a symptom of a failed globalization. As governments allow crude capitalism to take control of the internal commerce of a country, the political body loses its power to run the nation. This creates subaltern powers like drug and sex trafficking to get stronger and proliferate. In 'About the Future of LASA', Professor Roberto Follari gives a description of the situation of Latin America in the new millennium,

[...] it is true, then, that Latin Americans are justified in speaking of 'desperation' and that day-to-day life in our countries is indeed becoming increasingly desperate. Growing unemployment and marginality, permanent 
problems of security for the population, and increase in drug trafficking, a crisis in the normative adherence that guarantees social bonds, government corruption, galloping external debt, pressure from creditors organizations (Follari 2003: 4).

As Andújar, the detective, searches for Herminia Toral, he denounces the political aspect of the United States and the way that this powerful country affects Puerto Rico (Di Paolo Harrison 2016: 31). Andújar and his educated friends think that the USA is a power that controls and abuses the territory of Puerto Rico. These men have a resentment for being a colony and for the poor treatment that they receive (Cintrón 2014: 31). Andújar says that 'the yanks... that came with the sound of fire in 1898 and practice force as a right until today (Cintrón 2014: 23). The detective's statement aligns with this idea of colony and force. In 'PIP Attributes the Declaration about Colonial Status', a newspaper article from El Vocero, manifests the discontent with 'the most recent hit and colonial humiliation' voiced by the General Federal Attorney before the Supreme Tribunal of the USA and admitting that 'the island continues being a territory without sovereignty' (Quintero 2015: 3).

Besides this complaint of colonial abuse, Andújar and his friend, Waldo, talk about the abuse of power and the control and compares it with Big Brother, the dictator character of 1984 by George Orwell and affirms that the United States (Di Paolo Harrison 2016: 32) is watching us even when we go to the bathroom' (Cintrón 2016: 33). According to the detective, the social barbarism that they live is not a regression to primitive times (Di Paolo Harrison 2016: 34). For Andújar, is a postmodern and technological barbarism' and explains that 'the United States patrols us from its satellites and military bases around the world... and that the neoliberal agenda of the right wing... dismantles the social benefits that have cost us a lot to achieve, any pretext is used for the yanks to introduce their imperial boots in any given country' (Cintrón 2014: 52).

Another issue that worries Andújar is the presence of a profitable subsystem that, along with the legitimate power, destabilizes present day societies (Di Paolo Harrison 2016: 33). In Perspectives about Naval Strategies: Essays of the Americas, Paul Taylor explains that 'as globalization increases, the threats to the world and regional system emerge and evolve' (Taylor 2007: viii). What Andújar laments is that the world interests of the United States oppress the most fragile economies (Di Paolo Harrison 2016: 33). As Taylor says, the possibility of taking advantage of other nations is guaranteed and protected by a structure of autonomous webs of trade, capitals, communication, regulations, individuals and government administrations (Taylor 2007: viii). 
From all of these complaints, Andújar concludes that 'from the other side of the yanks imperialism raises drug trafficking, sex trafficking, the most horrible crimes to domesticate the opponent' (Cintrón 2014: 52).

These powerful alternative powers that arise from the control and oppression of strong economies and a system that benefits the rich, in order to protect their control, they go as far as murdering innocent women. Those women who try to escape are inevitably murdered. In the novel, Herminia and Liliana are assassinated. The male power of the trafficking gang reverts to femicide in order to maintain its control and dominance over the wounded bodies that they create.

In 'Femicide: The Scourge That Kills 12 Women A Day in Latin America', Lorena Arroyo brings to light that 'every two hours, a woman dies in Latin America for the simple fact of being a woman' (Arroyo 2017: 1). This is a serious problem in all of the Latin American region. In regards to Puerto Rico, the Department of Family Services, a local governmental agency, provides services to children, but there is not an agency in place for adults. There is not an organization exclusively for victims of sex trafficking. What is worse, government officials have denied the existence of this serious problem (Cabezas 2016). Much needs to be done in Puerto Rico to eliminate this atrocious business that creates injured bodies that are vulnerable and in danger of being murdered. In the novel, the narrator describes the femicide of Liliana Vidocq. A bullet went through an open window 'and crashed against the forehead of Liliana Vidocq. The woman collapsed against a table as she spilled the coffee that she had in front of her' (Cintrón 2014: 177). The man who was trying to protect her 'screamed and went to pick her up but when he looked at the exit hole, that looked at him with a sinister aura of blood, hair, bones and pieces of encephalic mass, told him that there was retreat' (Cintrón 2014: 177).

As this trafficking gang commits crimes and comes out unpunished by the law, the novel shows how government agents are involved in the sex trafficking business. The Center for Help to the Dominican Immigrant (CAID is part of the cartel. Clients are also politicians, business men, professionals, and rich individuals (Cintrón 2014: 206, 207). As the problem in real life does not improve, the novel presents a never-ending circular ellipsis. The detective laments that 'sex trafficking is an environment of relentless predators, that the Master was able to escape, and that many others would probably be lining up to take his place' (Cintrón 2014: 216).

\section{Conclusions}

To acknowledge this pressing matter, the Ricky Martin Foundation sponsored research on this topic in three occasions: Human Trafficking: An Invisible Challenge (Hernández and Angueira 2010), Human Trafficking: 
Modern Slavery in Puerto Rico (Hernández and Angueira 2014) and Gender Violence and Trafficking (Hernández and Angueira 2017). The 2017 report continues to stress how Puerto Ricans still do not recognize sex trafficking and femicide as a reality, because the members of this society believe themselves as civilized (Hernández and Angueira 2017: 13). In addition, it includes the latest recommendations to reduce the severity of the problem. The research concludes that the Office of Women's Affairs needs to educate the staff about sex trafficking and improve the quality of the interviews. The legal system needs to amend article \# 54 to add sex trafficking under the gender violence umbrella and define it as a crime. Also, the government needs to pay more attention to Dominican immigrants for being the most vulnerable sector on the island (Hernández and Angueira 2014: 50-51).

Mattos Cintrón's novel, from the fictional realm, creates awareness of the severity of this issue. As in real life, the text unveils the perils of Dominican immigrants who are helped to cross the Mona Passage, illegally smuggled in Puerto Rico and enslaved into prostitution. They are suffering and injured bodies that do not have the resources to free themselves from this agony. Women who try to escape are captured and forced to continue being a corporeal commodity, always in fear for their lives. The trafficking business is quite profitable and, in order to protect it, the bands are capable of committing femicides without remorse.

Puerto Rico has not completely embraced the fact that sex trafficking and femicide are tangible problems and that they need to be eradicated to protect women and children from the island and illegal immigrants that reside within this U.S. territory. Poverty and violence are increasing at a rampant pace. These factors have a direct relation with enslavement and the killing of women for the mere fact of their gender. Despite the efforts of the Ricky Martin Foundation, injured bodies continue to suffer the violation of their human rights.

\section{References}

Arroyo L (2017) Femicide: The Scourge that Kills 12 Women a Day in Latin America. Univision News. Retrieved from https://www.univision.com/univision-news/latin-america/femicide-the-scourge-that-kills-12-women-aday-in-latin-america.

A Gendered Analysis of Violent Death (2016). Small Arms Survey Research Notes. Retrieved from http://www.smallarmssurvey.org/fileadmin/docs/HResearch_Notes/SAS-Research-Note-63.pdf.

Barry K (1995) The Prostitution of Sexuality: The Global Exploitation of Women.

New York, NY: New York University Press. 
Bograd M (2005) Strengthening Domestic Violence Theories. In Sokoloff N and Pratt C (eds), Violence at the Margins: Readings on Race, Class, Gender and Culture. New Brunswick, NJ: Rutgers University Press, pp. 25-38.

Cabezas A (2016) Invisible Dominican Women: Discourses of Trafficking in Puerto Rico. Cuadernos Pagu 47: 40-57.

Centeno TD (2000) Immigrantes en el suelo Boricua. Oportunidad para mirarnos en el espejo caribeño. Diálogo 4: 5-8.

Chiarotti S (2004) Trata de mujeres: conexiones y desconexiones entre género, migración y derechos humanos. In Castillo $\mathrm{M}$ (ed) Derechos humanos y trata de personas en las Américas. Santiago de Chile: CEPAL, pp. 43-71.

Coormaraswamy R (1994) United Nations Special Rapporteur for the Commission on Human Rights on Violence Against Women, Its Causes and Consequences. Retrieved from http://193.194.138.190/html/menu2/7/b/mwom.htm.

Da Lomba S (2004) The Right to Seek Refugee Status in the European Union. New York, NY: Intersentia.

Di Paolo Harrison O (2016) Noir Boricua: La novela negra en Puerto Rico. Puerto Rico: Isla Negra Editores.

Doezema J (2001) Ouch! Western Feminists 'Wounded Attachment' to the 'Third World Prostitute'. Feminist Review 67: 16-38.

Dominican Republic: Poverty and Inequity Persist in spite of the Promises (2012, December 7). Retrieved from http://www.socialwatch.org/node/15613.

Follari R (2003) Acerca del futuro de LASA. LASA Forum 34(3): 4.

Hernández C, Angueira L (2010) Human Trafficking in Puerto Rico: An Invisible Challenge. Río Piedras: University of Puerto Rico.

(2014) Human Trafficking: Modern Slavery in Puerto Rico. Río Piedras: University of Puerto Rico.

(2017) Gender Violence and Trafficking. Río Piedras: University of Puerto Rico. Mattos Cintrón W (2014) Life is a Sexually Transmittable Disease. Puerto Rico: Ediciones La Sierra.

Nwosu C, Batalova J (2014). Immigrants from Dominican Republic in the Unites States. Retrieved from https://www.migrationpolicy.org/article/immigrants-dominican-republic-united-states.

Parrot A, Cummings N (2006) Forsaken Females: The Global Brutalization of Women. Lanham, MD: Rowman \& Littlefield.

Quintero L (2015) Al desnudo de la colonia. El vocero de Puerto Rico 3-4. (2015) PIP se atribuye declaración sobre estatus colonial. El vocero de Puerto Rico 4-6.

Ritchers A (1994) Women, Culture and Violence: A Developmental, Health, and Human Rights Issue. Linden: Women and Autonomy Centre (VENA). 
Siddharth K (2010) Sex Trafficking: Inside the Business of Modern Slavery. New York, NY: Columbia University Press.

Soriano J (2000) Trafficking in Sex. Retrieved from www.shewire.com.

Taylor P (2007) Perspectivas sobre estrategia marítima: ensayos de las Américas, la nueva estrategia marítima de EEUU y comentario sobre una estrategia cooperative para el poder naval en el siglo XXI. Rhode Island, NY: Naval War College.

Vlachová M, Biason L (2005) Women in an Insecure World: Violence against Women. Facts, Figures and Analysis. Geneva: Centre for the Democratic Control of Armed Forces.

Zepeda Patterson J (2015) Escribir policial acá es un desafío brutal: los héroes clásicos no son verosímiles. Interview by Gaffoglio L, La Nación Cultura, pp. 2-4. 